\title{
EXPLORATION OF SUPERVISOR AND STUDENT EXPERIENCES DURING MASTER'S STUDIES IN A HEALTH SCIENCE FACULTY
}

\author{
U. M. E. Chikte* \\ Executive Head: Department of Interdisciplinary Health Sciences \\ e-mail: umec@sun.ac.za
}

\section{J. A. Chabilall*}

Postgraduate Researcher

Department of Interdisciplinary Health Sciences

e-mail: chabilalli@sun.ac.za

*Stellenbosch University

Stellenbosch, South Africa

\section{ABSTRACT}

Significant growth in postgraduate student numbers with seemingly little change in staff composition and supervision capacity have prompted the need for research into the experiences of supervisors in a diverse interdisciplinary health sciences department. This article contends that supervision strategies form an important facet of institutional knowledge sharing in an interdisciplinary context especially in developing the capacity of postgraduate students to apply competencies later within the macro society in a sustainable manner. The article addresses one of the research questions of a larger study: What are the experiences of supervisors during the supervisory process of master's students in a Health Science Faculty? Supervisors were of the view that they were committed to their supervision duties. Their multiple roles meant that they had to be encouraging, understanding, empathetic, set boundaries, be supportive while they act as guides and mentors who are expected to provide timeous and continuing feedback. To provide a comprehensive appreciation of the study, the article also presents significant findings from the qualitative component pertaining to student-views of the supervision process. Recommendations relate to the workload of supervisors, faculty development and greater access to resources including funding that would generally influence postgraduate supervision.

Keywords: supervision, supervisors' experiences, master's studies, postgraduate students, higher education

\section{INTRODUCTION}

Significant growth in postgraduate student numbers with seemingly little change in staff composition and supervision capacity have prompted the need for research into the experiences 
of supervisors and students in an interdisciplinary health sciences department in a health sciences faculty. Supervision strategies form an important facet of institutional teaching and learning especially in developing capacity of postgraduate students to apply competencies later within a broader society in a sustainable manner. Competent research supervision, support of postgraduate students and capacity development are considered critical to the process of continual knowledge generation crucial in the global arena (National Planning Commission 2011). Encouragement and assistance for postgraduate students is 'an essential component of the national system of innovation of modern industrialized societies' (Council on Higher Education 2009, ix). An investigation, by Albertyn, Kapp and Bitzer (2008), into the experiences and achievements of postgraduate students who had completed their degrees, ascertained that the students' needs are affected by the transformations taking place at South African universities in the quest to be part of a global knowledge arena. Postgraduate supervision is accepted as a specialized skill that needs to cater for the increasing numbers and diversity of South African postgraduate student populations in terms of ethnicity, culture, class as well as language and educational background. The Department of Interdisciplinary Health Sciences (DIHS), in the Faculty of Medicine and Health Sciences at Stellenbosch University, compromises several distinct academic and professional divisions with different health research interests and staff with varying teaching and supervision capacity. The DIHS comprises diverse health professional divisions which are the Occupational Health, Physiotherapy, Community Health, Family Medicine and Primary Care, Human Nutrition, Centre for Rehabilitation studies, Speech-Language and Hearing therapy, Nursing Science, Emergency Medicine and the Centre for Evidence Based Health Care. As a result of the growing student numbers and shortage of qualified supervisors and the range of research topics being embarked upon, it often becomes necessary to allocate supervisors from different divisions within the DIHS and other departments depending on the professional or academic focus necessary. This teaching and learning complexity creates a uniqueness that necessitates that all qualified and competent supervisors develop a multitude of conceptual, methodological and theoretical skills to cater for interdisciplinary functions.

Wilkinson (2011) avers that supervisors generally engage with their students by applying policy and practice techniques they remember from their own period of study. Discovering how supervision practices of master's students is conducted in the DIHS, required engagement with those who find present contexts and strategies challenging - both supervisors and students. The overall research question addressed was: How can postgraduate supervision as a scholarly academic practice in the DIHS be enhanced? This article talks to the findings in relation to the 
following:

What are the experiences of supervisors and students during the supervisory process of master's students in a Health Science Faculty?

The objective of the study was to establish the context of the experiences of supervisors and students that would influence student success and throughput in the DIHS.

\section{BACKGROUND}

Bosch and Taylor (2011) affirm that the demand at higher education level for research innovation is often influenced by the managements' capacity to inculcate commitment towards competent research. Hence, research capacity, effective writing skills that underpin postgraduate studies and the nature of supervisory relationships determine the rate at which academics develop as effective teachers and researchers (Bosch and Taylor 2011). Adeyemi and Adeyinka (2003, 428) refer to this relationship and academic development as being the process of 'interaction between the guardians and seekers of knowledge'. Research discussed in this article derives from an overall project that explores the needs and experiences of master's students and supervisors in the DIHS and was driven by the need to establish the uniqueness thereof seeing that these are largely part-time health professional students. The DIHS has seen an exponential increase in postgraduate students in terms of numbers, diversity and the fact that many of the students are in full time employment and embark on postgraduate studies on a part time basis. At the same time staff numbers in the various divisions of the DIHS have generally remained the same thus increasing teaching and clinical loads in fields of health professional training.

The University of Stellenbosch is identified as one of the research intensive universities with the institutions Teaching and Learning Policy (2013) calling attention to a research-driven modus operandi to allow the increasing numbers of postgraduate students to be able to hold their own in the global context. Interdisciplinary collaboration within higher education transformation and in a healthcare professional context has subsequently stimulated a call for similar activities and responses among students at Higher Education faculties where health education and research are priorities (Gebbie et al. 2007). Winberg et al $(2010,191)$ make a significant contribution to the discourse reflecting upon existing ' ... approaches to (rethink) the research practices of academic staff and their supervisors in ways that acknowledge the complexity and the significance of multi-actor, multi-level local, national, international and global interactions'. Thus, research and supervision at higher education level is meant to include 
diverse interfaces linked to teamwork that aims to achieve common patient care goals which subsequently shape postgraduate research and impact on society at large (Swanepoel 2010) but there is no 'prescribed or formal preparation' Maritz and Prinsloo (2015, 973), who (Maritz and Prinsloo 2015, 974) propose that:

Many supervisors in turn see the supervision process as (also) a process of enculturation whereby students are seen as novice apprentices in a particular field and introduced to the epistemologies and the ways of thinking and being inherent (and accepted) in a particular discipline. In this approach, supervisors are often seen (whether by themselves or by students) as the gatekeeper(s) to the qualification and the academic discipline ...

This study acknowledges that the students enter the programme with different prior educational experience or training, research capability, clinical commitments and professional backgrounds. While there are some challenges specific to the supervisory process, there are others unique to issues of capacity, research skills and teaching in the DIHS as a diverse department within the Faculty of Medicine and Health Sciences. Preliminary investigations within the DIHS found that there is a lack of adequate and suitably experienced supervisors to teach large numbers of diverse postgraduate learners about a range of research methodological approaches. This shortcoming does not help students who wish to complete their master's in the allocated time. The supervisory process is also an arduous task for students as well as supervisors who are sometimes overwhelmed by their teaching, administrative duties and postgraduate supervision tasks. Instiutional policies, practices and procedures. Causal factors such as institutional policies, processes and regulations subsequently compound the drop-out rates as students are unable to compensate for their lack of scientifically rigorous research skills under these circumstances. Students are especially at a disadvantage because of the lack of adequately trained supervisors who can provide assistance and guide them to develop their research and writing skills. While the various divisions in the DIHS experience such postgraduate supervision challenges the same holds true in terms of postgraduate studies at other institutions.

\section{SUPERVISION CAPACITY IN THE PROCESS OF MASTER'S INTELLECTUAL INQUIRY}

Limitations in terms of supervision capacity affect South African academics generally in that they become the overworked lecturers and supervisors. This phenomenon is especially noticeable in the Faculty of Medicine and Health Sciences where qualified health professionals face the challenge of academic responsibilities in addition to clinical engagement. Teaching 
and learning embraces the format of set curricula, where one objective is also that students are competent enough to step out into the professional world with knowledge of the operational skills required by the profession. The onus is on South African institutions to enable postgraduate students to engage in their research with present social, educational, health and economic challenges competently in a spirit of consultation and collaborative decision-making to achieve more constructive research results and at the same time throughput rates. To overcome the challenges associated with equity transformation, academics such as Van Biljon and de Kock 2011) and Badat (2008) believe that the country needs to overcome the 'racialization and gendering of higher education that occurred under colonialism and apartheid'. It is also Badat's $(2008,2)$ assertion that the emphasis ought to be on 'producing and retaining a new generation of academics’ who are also proficient postgraduate supervisors.

Akoojee and Nkomo (2007) are of the view that while many postgraduate students lack the research skills for the reason that they come from backgrounds that have not provided them with the basic foundations, supervisors are nevertheless required to maintain timeous throughput (Winberg et al. 2010). Success rates in terms of master's students at South African higher education institutions have increased from 2007 to 2012 (CHE 2014). Transformation in South African Higher Education has meant that there is a need for these institutions to cater for the 'rapid massification of the student body' (Council on Higher Education 2009, 1) and as a consequence students registered for master's studies. The process 'inevitably puts strain on the resources of the universities' (Council on Higher Education 2009, xvi) and impacts upon postgraduate throughput. Institutions are also challenged each year to produce a larger number of competent supervisors to support postgraduate students resulting in complications that are sometimes difficult to resolve. Institutional postgraduate selection criteria and processes in addition to administrative policies and implementation measures are affected because of increasing numbers of postgraduate students. Further, the degree of social and academic integration among students (Tinto 1975) and levels of their administrative understanding affect postgraduate retention and success.

The view in this article is that the progress of master's students from enrolment to graduation is strongly affected by students' and supervisors' access to resources that generally enhances the quality of teaching and learning, of which supervision is an integral part. In keeping with Bourdieu's (1986) notion, supervision relationships and networks may be considered to be the social capital that can provide the student and supervisor with resources and expert knowledge to address the challenges that come with the supervision process. Van Biljon and de Kock, (2011) reflect on the dynamics in supervision relationships where they 
established that the way in which supervision is conducted can be a key contributory factor to the accomplishment of satisfactory postgraduate throughput rates. Alternatively, in Mouton's (2007) examination of myths and misconceptions within the context of postgraduate studies in South Africa, he is critical of the fallacy that the delayed postgraduate completion, dropout and throughput rates are as a result of the inferior quality of supervision relationships and management. It is his assertion that there has been a vast improvement in postgraduate student enrolment and graduation in the last ten years. Therefore, academics qualifications have been advanced, postgraduates have facilitated greater research output and funding opportunities for institutions of higher learning (Mouton 2007, 1089). While he acknowledges evident shortcomings he emphasizes that the achievements in South African higher education are noteworthy in the face of the many institutional and curricular reformations post-1994. Mouton (2007, 1090) refers to 'systemic issues' necessitating greater action to address problems such as the 'many overburdened and inexperienced supervisors'. It is also his suggestion to increase funding that will build the supervisory capacity of employed academics.

\section{CHALLENGES WITHIN THE SUPERVISORY PROCESS}

Bitzer (2007) proposes that the supervisor's level of research and teaching competency can facilitate progress towards shaping a University's progress towards its academic and financial goals. Universities advocate that there ought to be a continuous flow of postgraduate students and supervisors to cultivate research competence and new scientific knowledge. Accordingly, the contextual relevance of capacity building not only for the students but for supervisors as well, becomes embedded at research-orientated Universities. The article takes cognizance of Scott, Yeld and Hendry's (2007) argument for creativity whereby additional capacity building exercises facilitate and enhance supervision strategies that form a vital part of teaching and learning. As the on-going process of capacity building and scientific writing helps to build the pool of competent supervisors, recognized scholars who are able to demonstrate strong supervisory skills and relationships will emerge (Winberg et al. 2010). In turning to Koen (2007, 25), who draws on Tinto's $(1975,2002)$ theoretical approach to support his research stance it is accepted that social interactions can contribute negatively or positively to students' goals (Koen 2007, 64). Tinto’s theoretical assertion that advocates that institutional culture, social elements, integration and commitment are key constructs in any institutions efforts to develop student throughput. Although Tinto's model is more specific to undergraduate student retention, the arguments hold true for this article in that Tinto (1975) expanded upon student enrolment and their appreciation of complex administrative, intellectual and academic 
requirements.

Scott et al. (2007) concede that there is a strain upon existing academics and a drain on institutional financial resources as a result of the demands and challenges - which means that this affects the retention of master's students and throughput. The proposal presented by Scott et al. (2007) infers that the supervisors too will feel increasingly burdened by the number of students they have to supervise and the need to measure up to ever-changing teaching and learning strategies. A discussion of effective research supervision (Nsibande 2007, 1117) deliberates the 'currere' that may enable supervisors to discover their personal insight into the practice of supervision. It is the writer's (Nsibande 2007, 1124) perception that supervision training can result in 'self-introspection' and a fresh appreciation of the process and consequently a more favourable postgraduate throughput. Accordingly, the study suggests that supervisors will recognize that postgraduate students are to be stimulated intellectually about the theory of the research focus area and the accepted research modus operandi. Nsibande's (2007, 1120) argument is that the nurturing relationship of supervision will be beneficial to students if they are guided to understand the research per se while being encouraged to work at an intellectually emancipated level of inquiry.

Olivier $(2007,1126)$ communicates the importance of 'knowledge management' in addition to teaching and research within a supervision context. The objective of Olivier's (2007, 1130) 'self-reflective enquiry' was to depict his personal supervision relationships in order to modify these to improve the outcomes for the students as well. Further, Olivier (2007) aimed to create mutually beneficial relationships and students who become independent thinkers. Waghid (2011, 393) contends that 'postgraduate student supervision ought to be an encounter framed by scepticism'. He is of the view that the human element of the supervision relationship will control the nature of the relationship. It is Waghid's $(2011,396)$ argument that supervisors have a responsibility to 'create opportunities' for their students 'to think, argue and write their texts'. Madikizela-Madiya, Busisiwe and Nkambule (2013, 941) emphasize 'trust, collaboration, power and conflict resolution that could occur through explicit communication between members' who may be supervisors and masters students for the purposes of this article.

In summary, the literature reviewed in this context illustrates that the research product is significantly influenced by resources as well as academic and administrative support offered by the institution; the levels of supervisor motivation, their expertise, personal characteristics, skills and commitment; and the expectations, preparedness, competency and diversity of the students. Hence, the model of supervision offered by the institution ought to include training and information strategies that enhance generic, research and academic skills thus providing for 
capacity and diversity demands thereby enhancing postgraduate education and developing the student and supervisor as researchers, supervisors and academics.

\section{METHODOLOGY}

The research that was conducted in the DIHS consisted of two parallel studies featuring a quantitative study that required that master's students complete a questionnaire and a qualitative study that entailed interviews with supervisors. In order to fulfil the objectives of the qualitative process, a total of sixteen (16) supervisors were conveniently recruited into this study from the various divisions of the DIHS. Appointments with the heads of divisions realized the recruitment of supervisors of master's students who were willing to participate in the study. The number of interviews was influenced by the need to have equal representation of supervisors from each of the divisions. This study was also aimed at establishing the experiences of three different groups of masters' students - those who had completed their studies, those who were still enrolled and those who had terminated their studies. The intention was that the questionnaire would be completed by a representative sample of about 200 masters' students. As a result of problems relating to obtaining contact details of the students, it was decided that questionnaires were to be sent to all students whose email-addresses were available. In total 541 questionnaires were distributed. Of these 48 could not be delivered and 112 were completed and returned.

Ethical approval for this study was obtained from the Health Research Ethics Committee of the Stellenbosch University (SU), South Africa, after which semi-structured face-to-face interviews were conducted with the sample of supervisors. These interviews were conducted between August 2011 and December 2011 on a one-on-one basis in the supervisors' offices. The supervisors were fully informed of ethical approval and the protocol in terms of recording, transcribing and analysing the interviews. Researchers were explicit about the research and ethical conditions stipulating that they conduct the interviews anonymously, and that the identities of the supervisors will not be mentioned anywhere. The appreciative inquiry method was used as far as possible using a set of questions to guide the conversation. Interviews were digitally recorded, transcribed and qualitatively analysed by applying qualitative content analysis using ATLAS.ti. software. The process of open coding was applied after which categories and themes were identified. Validity and reliability of this study depended on the veracity and transferability of the findings or the extent to which the findings matched the reality within the Faculty. Researchers ensured that multiple constructions presented reliable findings in terms of supervisory process and the departmental requirements. To achieve 
credibility the researchers made use of triangulation, respondent validation and clear-cut descriptions. Strategies were put in place to ensure validity and eliminate risks particularly in terms of distortions generally created by the use of audio-tapes, interview transcripts, and running field notes to capture data. Care was taken to train researchers to be sensitive and reflective in the way questions were presented and how such data was accessed. Researchers also made use of reflexive techniques to exhibit the rigour and trustworthiness of the findings.

\section{RESULTS}

The categories and themes identified from the data are diagrammatically presented in Figure 1. The outer circle (Figure 1) represents the postgraduate system of the institution, the supervisor and the student. The inner circle represents the more tangible aspects of the postgraduate process for example the models of supervision and training.

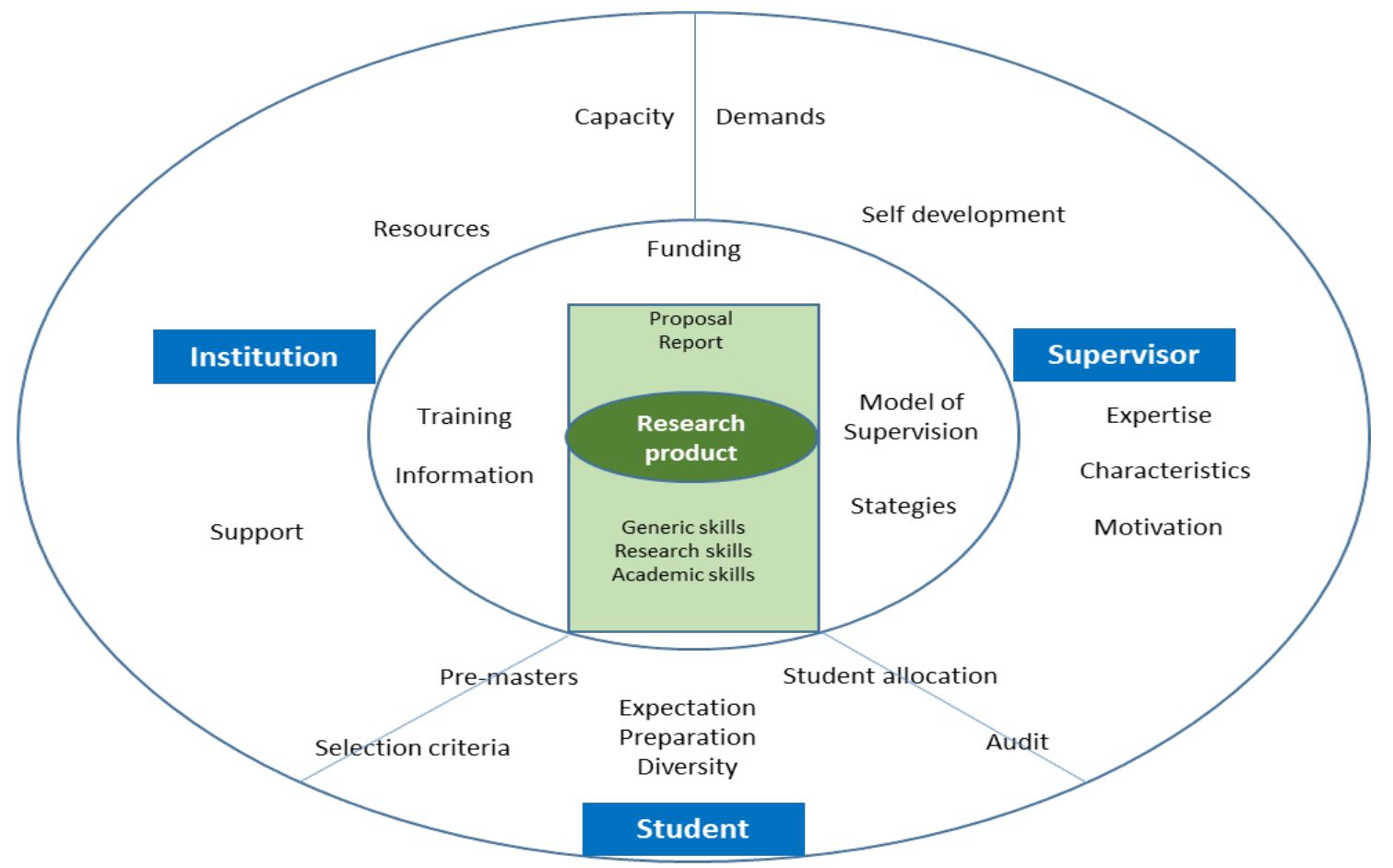

Figure 1: Supervisors' experiences of supervision of the research component of their master's studies

Aspects in Figure 1 of relevance to this article are the institution, the research product, supervisor and the master's student. The outer circle represents the postgraduate system of the institution, the supervisor and the student. The inner circle represents the more tangible aspects of the postgraduate process for example the models of supervision and training. The major themes will be discussed fully in conjunction with sub-themes using evidence in terms of the 
experiences of supervisors and students under the respective theme headings.

\section{Institutional factors}

Institutional factors include information, support, resources and the formal preparation of students. Information is required for students and for supervisors in terms of the administrative protocol of the institution, policies, procedure and regulations pertaining to postgraduate studies. A guide regarding administrative details and selection criteria is essential and should be current and readily accessible to supervisors, co-supervisors and students. In many cases this criteria is in place and information regarding deadlines, funding opportunities and research support can be easily accessed. Available training support is important for the development of supervisors. One supervisor noted that apart from an understanding of the institutional rules and regulations it will also be beneficial if there is some form of practical assistance from experienced supervisors:

Dit het nie net al die reëls en regulasies en prosesse vir jou uiteengesit nie, maar dit was praktiese leiding deur iemand wat al honderde studente leiding gegee het. Dit is baie sinvol [It is not just all the rules and regulations and processes that are explained, but it is the practical guidance by someone who has supervised hundreds of students. It is very meaningful] (Supervisor 6).

Thus, the implication is that although institutional information and resources were essential, it is also important that there is ongoing support for the supervisor so that the level of supervision satisfies the objectives of postgraduate education. Hence, as one supervisor says, '... skills in supervising, the workshop, yes, is a nice thing to do, but it is probably also about sustained support. I will say, some kind of platform now on a higher level, not just for the masters students, but also for the supervisors, we you can kind of share experiences that have worked; things that don't work; frustrations with a particular master student that don't do what you tell them, know how to get them to do it, how to get out of that situation.' (Supervisor11).

This kind of support initiative can be provided across disciplines in the DIHS. Training is important for all co-supervisors especially if they are external supervisors as institutional disparities may cause difficulties for the students. This concern was raised by one supervisor:

I had supervisors, on a part time basis, that phone me and say please, tell me what I am supposed to do. I was just assigned these students. I am supposed to supervise; I have never done it; I don't know what is expected; and I had to support supervisors via telephone and e-mail. That is not my role. And that is because of failure upstream and that is something that could be changed. And it will have a huge impact on all the lecturers, supervisors and most importantly, the students' throughput. (Supervisor 13) 
This excerpt illustrates the views of an experienced supervisor who felt weighed down by the demands of a newly appointed supervisors who did not have the capacity to carry out the task of supervision without continual guidance and support. The recommendation was that the institution and faculty ought to provide training and support for supervisors to ensure that the standard of postgraduate research output is not compromised. In addition, institutions ought to provide support by allowing supervisors time off for research; ensuring that there are funds for staff substitution; using consultants and promoting sponsorship of training initiatives (researchrelated, generic or supervision training). The roles and responsibilities, specifically of the cosupervisor, also require attention according the research participants.

Generally, supervisors are doubtful whether the idea of a formal pre-masters short course is practical due to resource implications. They express the idea that the course may have value but will not necessarily be feasible or appealing to students. Although the idea of some sort of bridging for underprepared students was acknowledged and welcomed, the formal pre-masters qualification was not considered the best route to pursue.

\section{The research product}

Although students are not required to be fully knowledgeable about their research areas and methodology at the outset, supervisors expect them to have read enough to write the research proposal.

... they must have a reasonably good idea what research is all about ... understand the real purpose of research and what kind of questions you can ask (Supervisor 4)

The supervisor is then engaged in the proposal writing and, in varying degrees, participates in conceptualization and finalization of the essential process for the student to finally embark on the study. These processes include approval at faculty level and ethical clearance. Students need to be taught elementary aspects of appropriate research methods, about integrity in data collection and may also need to be provided with guidance regarding the most appropriate research method for their study.

Supervisors are aware of the need for continual development '... there is a parallel with my self-development process ... and I need to read up more, understand more, ask more questions, I need to be consulting people as well' (Supervisor 2). They reported that they had attended research training '... al van die navorsingskursusse gedoen' [... done some of the research courses] (Supervisor 10). Supervisors themselves also need to have sufficient knowledge about the research methods and not just be experts in their discipline. 'En dis waar 
die probleme inkom. ... 'n student kan skryf wat hy wil en hierdie navorsing doen, maar op die ou einde is dit so skeef, want die supervisor het nie daardie kennis nie.' [And that is where the problems come in. ... a student can write what he wants and do this research, but in the end it is so skew, because the supervisor does not have that knowledge] (Supervisor 6).

According to the supervisors, students also need to develop generic skills and some supervisors refer students to university support that is provided. They agree that the students also develop during the course of their studies '... hulle taalkundigheid ontwikkel baie. Hulle wetenskaplike navorsingstaal ontwikkel' [... their language skills develop a lot. Their academic research language develops] (Supervisor 8). One supervisor noted growth and development through the process of research:

Ek en die studente wat ek al gehad het, groei - persoonlik, ongelooflik, hulle groei emosioneel, ongelooflik. Hulle leer om stress baie, baie goed te hanteer ... Want hulle doen kliniese navorsing. [I grow and the students have had to grow - personally, incredibly, they grow emotionally, incredibly. They learn very, very well how to handle stress ... because they do clinical research] (Supervisor 8)

Supervisor 9 maintains that student support and step-by-step feedback sessions bring success:

So we support our students throughout. We support our students from the inception of the research idea ... Formulating their research questions; refining their aims and objectives. Discussing the matters. So we can actually be comfortable with having our names as co-authors in these papers. You know, because we have gone through the whole process with the student. They come back with the results. This is where I see most of the work, because students have now done the field work. They have now the research results in front of them. So this is where they become almost paralysed and they then seek your advice to where to start and to what most important out of this mass load of results. How do I now correlate all of this and start discussing.

The findings show that the supervisor is fully involved in all the generic steps of research fundamental to the conventions of the discipline. However, the level of involvement of the supervisor in the research seems to vary, based on the individual needs of the student the expertise of the supervisor and the research approach that the supervisor adopts. Supervisor 9 makes the point that when there is this form of active participation involving both student and supervisor in the research and writing processes then contributions to publications are shared justifiably.

\section{Experiences of supervisors}

With reference to Figure 1, motivation, multiple roles, characteristics, models of supervision, approaches and strategies and meta-reflection categories represent the experiences of the 
supervisors of the supervision in the DIHS. There are multiple supervisory roles including personal relational roles such as being encouraging, understanding, counselling, setting a boundary, supporting and mentoring. Some examples are provided:

So daardie kommunikasie moet net oop wees die heel tyd. [So that communication should be open the whole time] (Supervisor 6).

... en hulle kort-kort herinner om te stuur anders gaan jy nie klaarmaak nie ... [... and often remind them to send otherwise won't finish] (Supervisor 5)

Other roles include mentoring, availability/contact, communication, timeous feedback, constant feedback, monitoring, and flexibility, managing, guiding and setting a timeline (Supervisor 1, 2, 3, 4, 6, and 9). The characteristics of supervisors influence the approach towards the postgraduate process:

I try to be fair (Supervisor 4)

... ondersteuning van die hele proses [... support of the whole process] (Supervisor 3)

Supervisors take on research supervision of postgraduate students as a part of their job description and '... want dit is my passie' [... because it is my passion] (Supervisor 9). These supervisors have positive attitudes towards research and see supervision as an enjoyable task, a calling and a challenge. They experience supervision as rewarding especially when a proposal is approved (Supervisor 8) and when an article is published (supervisor 12). The supervisors tend to have a heavy workload (Supervisor 1) so a balance needs to be maintained between support and independence (Supervisor 10) in order that they do not do too much work for the students. 'I think it is an exhausting process. It is absolutely exhausting. It is like doing another master's yourself' (Supervisor 2). Supervisors need to guide students to other consultants during the course of the process according to the student need and the supervisor's capacity and expertise.

Quality is a key component of master's studies - hence the need for careful monitoring during the course of the studies. Approaches and strategies during postgraduate supervision include the use of the Socratic approach:

... but that is why you have to ask questions and then try to be flexible. Sometimes students come up with ideas totally different from what you have, but it might be good. And you have to learn to accept that and that is hard, particularly when you get older, you have fixed ideas (Supervisor 4)

So jy word deel van die student se span. Jy word nie die student se opposisie nie in die proses nie. ... wat kritiek lewer op die student se idees nie. Jy word deel van die span wat saam met die student 
werk om 'n goeie eindproduk te kry. ... dit is moeilik partykeer om nie vir 'n student die antwoord te wil gee nie. So dit is ' $n$ kuns. ... ek het nou al baie geleer oor die tyd om, net deur goeie vrae te vra, om die studente te probeer kry om uit te kom daar waar hulle behoort te kom [ so you become part of the student's team. In the process you do not become part of their opposition who criticises the student's ideas. You become part of the team what works with the student to get a good end product. ... it is difficult sometimes to not want to give the student the answer. So it is an art. ... I have now learned a lot over time to by asking good question, to try and let the student arrive where they should be] (Supervisor 10)

Supervision strategies include clear guidelines to ensure compliance (for instance referencing) and examples of previous studies to indicate standards. Problems that jeopardise quality relate to poor selection of students and time pressure where students do not work consistently throughout the process and then rush to complete at the end of the allocated time to complete their studies. This urgency to complete challenges the supervisors' workload and compromises quality. Supervisors are aware of the need for growth and self-development: '... that one must improve as well, as a supervisor. I mean, I can’t just remain stagnant. I need to improve as well’ (Supervisor 9). Some supervisors have had formal training in supervision from various providers and noted the value of expertise and practical experience of trainers (Supervisor 6). Other supervisors have learned via informal means such as self-study or through apprenticeship or mentoring:

Ek het geleer deur my eie studie en die leiding wat ek daar gekry het en ook voorgraadse studiebegeleiding ... en ' $n$ mens leer ook deur na jou kollegas te luister en hoe hulle nagraadse studente ervaar en studiebegeleiding doen en hulle het ons ook opgepaar met iemand wat al ondervinding het en jy met die minder ondervinding, kom dan by [I learned through my own study and the supervision I got there and also from undergraduate supervision ... and a person learns by listening to your colleagues and how they experience and do supervision and they also paired us up with someone who has had experience and you with less experience join in] (Supervisor 10)

... omdat ' $\mathrm{n}$ ou nou al self daardeur is, weet ' $\mathrm{n}$ ou min of meer wat 'n student se verwagtinge is [... because you have been through it yourself you know more or less what the student's expectations are] (Supervisor 6)

... 'n beter studieleier nou as wat ek 5 jaar gelede was, want jy leer maar soos die tyd aangaan [... a better supervisor now than what I was 5 years ago, because you learn as time goes by] (Supervisor 5)

The supervisory role may be part of the departmental procedure '... ons probeer dan dat nuwe dosente dit dan eers saam met ervare studieleiers doen en dan later op hulle eie’ [... we try to then let the lecturer first work with an experienced supervisor and later do it on their own] (Supervisor 3).

External supervisors have become necessary with the increased demands on permanent 
lecturers' time. Their increased workload may be due to greater and diverse student intake and varying levels of preparation in registering students.

... dit sou nogal lekker gewees het as ons meer studieleiers gehad het, want die lading is nogal groot op die oomblik op die studieleiers. [... it would be nice if we had more supervisors, because the load on the supervisors is great at the moment] (Supervisor 1).

The use of external supervisors however, creates problems in terms of training the external supervisors to understand the roles expected of them, administrative procedures as well as problems due to low remuneration (Supervisor 10) and lack of security:

... a year or two year contract. So there is no job security ... you are always under threat and also the student does not know, will my supervisor be here in a year's time? The demand is there ... but they not investing in the staff. They just bring them in short term, but that send the message out, we don't really want you, ... modern slavery (Supervisor 13)

... teen R45 'n uur. Ek kan nie dit doen nie. Nie eens vir die liefde van die saak nie. [... for R45 per hour. I cannot do it. Not even for the love of the cause] (Supervisor 8)

The meta-reflection by the supervisors and examples of the issues they reflect upon are provided in Figure 2.

The meta-reflection of supervisors establishes the relevance of the level of involvement and influence on ownership of the research project. It also illustrates the nature of the supervisor's relationship with students as well as the degree of assistance and time allocation. There is also evidence of positive feedback versus negative correction. Clarity in terms of the question of student ownership of the project and the effect of the supervisor's reputation is provided. In addition, the meta-reflection expresses the supervisors' views regarding service to department, individual workload as well as the supervisor's level of involvement and responsibility towards the student.

\section{Experiences of students}

The quantitative aspect of the study established that students had registered for the master's programme for various reasons that were work-related, personal or a combination of both. Their responses also established that they remained motivated despite the various factors that they felt affected their progress as one student said:

I chose a topic that I liked; working in a field I am very interested in (Student 3)

... as jy min of meer ' $n$ idée het wat jy wil doen, maak jy dit makliker [If you more or less have an idea about what you want to do, you make it easier] (Student 8) 


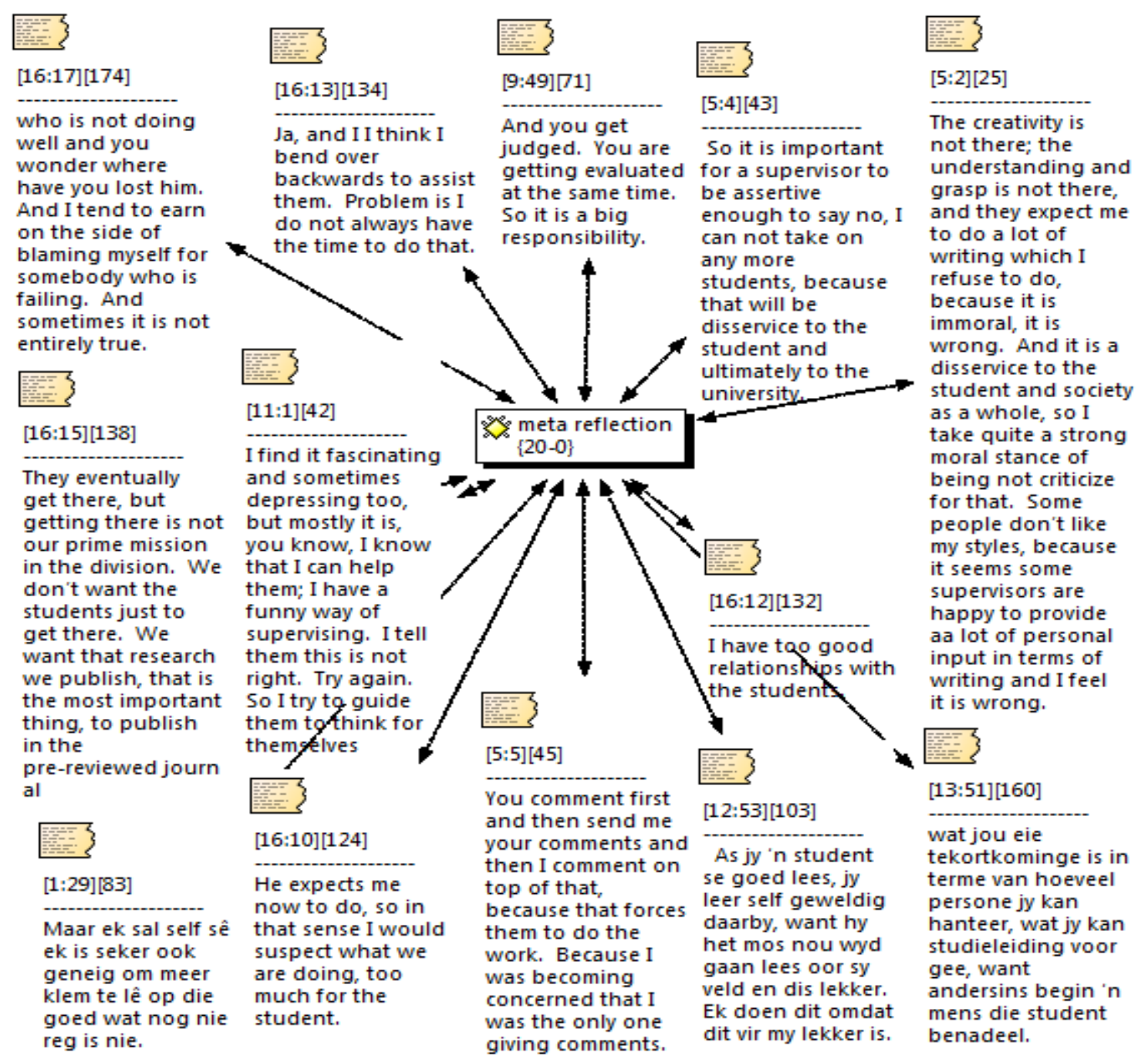

Figure 2: Meta-reflection of selected supervisors

... regtig gefokus was op wat ek wil doen, het vir my gehelp aan die einde. ... baie gedertimineerd om konsensieus te werk na ure. ... Ek het besef en geweet dit gaan baie werk wees. Ek was bereid om dit te doen en ek het geweet hoekom ek dit doen. [... was really focused on what I want to do, helped me at the end ... determined to work conscientiously after hours ... I realised and knew it would be a lot of work. I was prepared to do it and I knew why I was doing it] (Student 8)

According to students in the study, the supervisor's role is to direct the student and provide support in the development of the thesis. Findings show that students consider the contact between themselves and their supervisors necessary for the realization of their academic goals. The degree to which the student feels dependent upon the supervisor sometimes determines the extent and nature of contact between the two. As such, key aspects seem to be the supervisor's availability and commitment to the study: 
... ek kan hom enige tyd 'n epos stuur ... en 'n respons kry ... of die telefoon optel en sê ... ek het hiermee ' $n$ probleem, hoe benader ek dit, wie is die person wat ek moet kontak? [... I can send him an email ... and will get a response ... or I can pick up the phone and say ... I have a problem with this, how do I approach this, whom must I contact? (Student 4).

There is consensus among students that supervisors have to be available for meetings regularly. They find that in some instances contact is minimal or as one student pointed out there is no contact at all, which was frustrating. Students generally preferred to have email contact as this suited their needs best if they were part-time health care professionals.

Student respondents make the point that the supervisor's direct involvement with their study will assist them to enhance their work strategies, as one student stated: 'I was just very excited about the whole idea of doing a master's thesis and actually furthering my career' (Student 13).

There were statements that supported the idea that the supervision relationship had become problematic for some students. One student described the supervisor's role as one:

... to nurture the love of research. I think that is very important. Often the student and supervisor may not see eye to eye, but it is important even though you don't see eye to eye, that you don't kill that passion or that flicker ... displayed in I want to find out more. I don't have all the skills, that is why I am coming to you and to be a good facilitator (Student 16)

Admittedly, the supervision relationship was challenging at times as Student 10 found: 'you need some sort of inspiration and motivation and support and I found that really hard'. Other students appreciated the merit in having a positive supervision relationship:

So ek het ' $n$ baie gemaklike, oop verhouding met hulle gehad. Ek het nie vreemd of geintimideerd deur hulle gevoel nie. [I had a very comfortable and open relationship with them. I did not feel strange or intimidated by them] (Student 2).

At the same time there were comments that suggested that some students preferred some degree of independence where the supervisor allowed '... you free range as much as possible, but to guide you in areas you may not have been familiar with’ (Student 3). It became apparent from students' responses that they also appreciated supervisor-characteristics that exemplified patience and calm; approachability; positive attitudes; enthusiasm; constructive criticism; supervision experience; the ability to provide different expectations; and being good facilitators who displayed dedication and commitment. 
... encouraged every time; keep on reminding me to have fun and to enjoy it and I think that worked well for me (Student 3).

Within this co-operative context students make the assertion that they need supervisors to recognize that they are more than just students but that they are also human. Hence, they appreciate the fact that some supervisors recognize the need for social interaction between supervisors and students:

It really was very helpful and even getting me into you know, to become a part of one of the society's, XXX society, and always introducing me to something new (Student 13)

In contrast, there are students who make mention of unnecessary delays that hinder progress, conflicts within the supervision relationship or personal and work challenges that make them think that they are less likely to continue with their studies as a result of the negative experiences. Problems within the supervision relationship are exacerbated if the roles and responsibilities of student and supervisor are not being clearly defined. Students did concede that they appreciated that their supervisors were bogged down with administrative, teaching and supervision responsibilities that affected the attention they received or the timeous completion of the thesis. As a result, some students make mention of feedback that is sometimes delayed, while others commend many supervisors for their thorough and prompt feedback. For the student progress it is important that the supervisor's workload be considered:

... moet net besef om nie te veel studente te wil invat en dan gaan die kwaliteit daaronder lei nie. [... must just realise to not to want to take in too many students and then the quality will suffer] (Student 6)

... moet hulle meer mense aanstel as studieleiers, buite mense selfs ... die dosente kan nie by als uitkom nie. [... appoint more people as supervisors, even external people ... the lecturers can't get to everything] (Student 2)

\section{REFLECTIVE CONCLUSIONS}

This article demonstrates that the experiences of supervisors and students during master's studies call for many changes within the supervision process in the DIHS as a result of the increasing number of postgraduate students who register at higher education institutions. The relevance of 'knowledge-building activities' within the framework of postgraduate education has been evaluated by (Winberg et al. 2011, 1003) who indicate that the future of research at higher education level will move towards complex issues within interdisciplinary models. To keep up with this transition Winberg et al (2011) suggest that teaching, learning and research 
supervision has to be adapted accordingly. In applying Tinto’s (1975) theoretical context the article concludes that levels of administrative knowledge among students and supervisors does affect retention and success among master's students. Suggested modifications emphasized by both supervisors and students in the study include steps to resolve institutional procedure issues, enhance research and writing development, intensify training and development activities and deal with relationship conflicts between students and supervisors as depicted in the Figure 3.

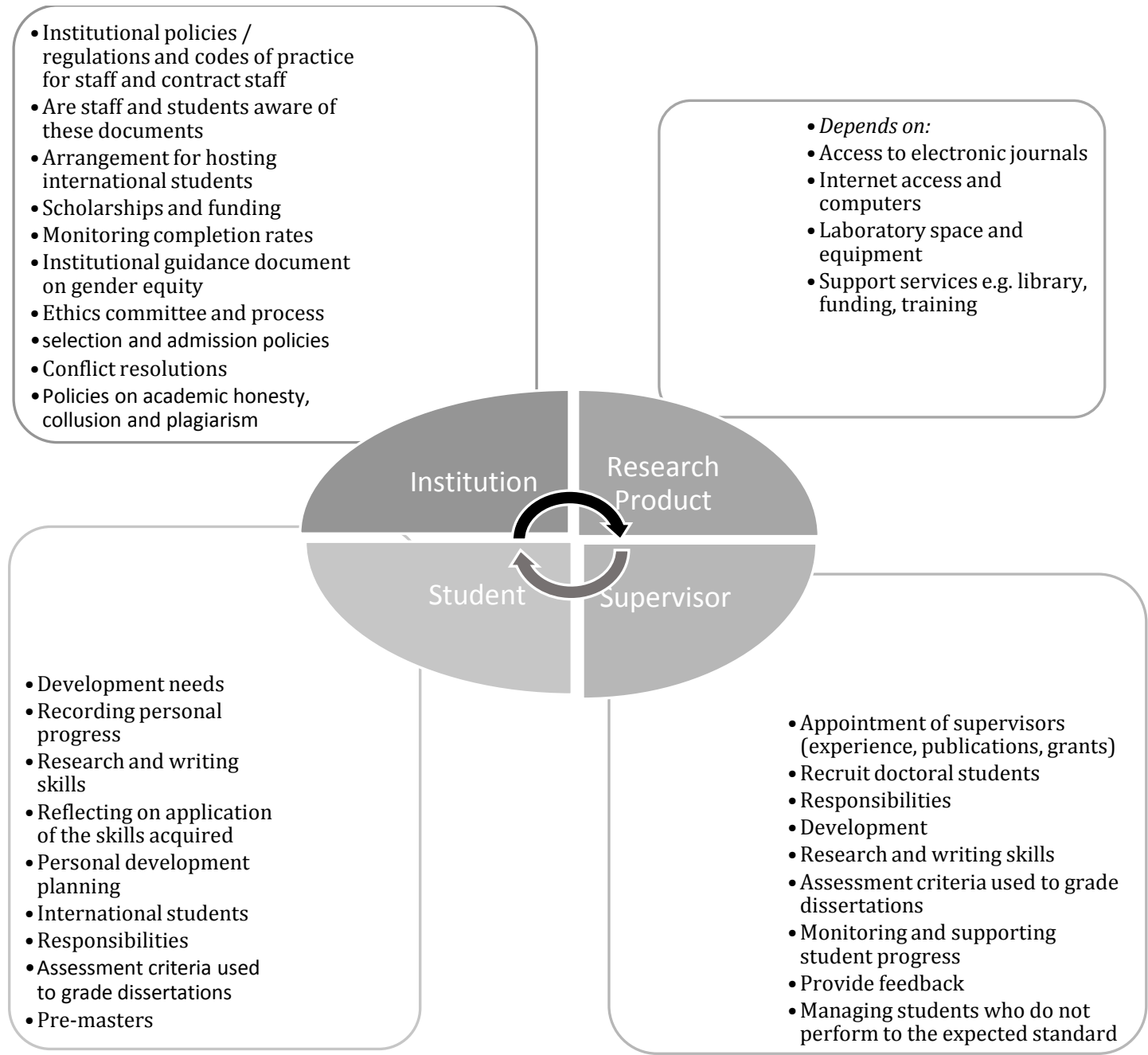

Figure 3: Criteria for successful postgraduate research supervision

The article highlights that the administrative, research and writing conditions under which supervisors and students work will determine postgraduate success especially if such research is ultimately intended to have the necessary social impact (Swanepoel 2010). As Badat (2008) suggests, developing a new generation of researchers and academics with supervision competence necessitates an academic and a research environment where concerns are identified and addressed, for communication channels to be open, and for roles and responsibilities to be 
clearly defined. Disagreements around supervision may also be overcome if the institutional documents and supervisory contact sessions are clear and available. There ought to be careful selection of students as well as realistic timelines for each to avoid resultant pressure if students do not work consistently throughout the process and then rush to complete at the end of their studies. Such haste produces challenges for the supervisor whose workload is increased and for the thesis that may lack quality.

This article has demonstrated that clear channels of communication between the student and the institution and the student and the supervisor can help to avoid situations where students are unnecessarily admonished for misinterpretation of feedback or ignorance. The article further adds that supervisors in this study within the DIHS refer to challenges relating to levels of prior knowledge and preparation among students. As Akoojee and Nkomo (2007) have found, supervisors maintain that they do not always have a way to ascertain students' research skills other than the results from previous qualifications which may not be helpful indicators of aptitude for further study. The suggestion made by the DIHS supervisors is that a skills audit can be a way of establishing the needs of students. The article further demonstrates that a balance between supervisor support and student independence is important and can be regulated via a contract between the student and the supervisor. Competent and confident supervisors will guide students to other consultants or experts during the supervision process according to the student's needs and the supervisor's capacity and expertise.

Findings discussed illustrate that it is essential that support for the development of all categories of supervisors include training workshops where they can share experiences that have worked; things that don't work; frustrations with particular students where problems arise and options to resolve conflict. This kind of support initiative can be provided across disciplines to achieve successful throughput as Winberg et al. (2010) suggest. In addition, the findings as discussed in this article indicate the need for the use of a monitoring system to control quality during the course of the studies where specific strategies are needed. These include clear guidelines to ensure compliance (for instance referencing) and examples of previous studies to indicate standards.

The study confirms that supervisors as well as students pursing the master's degree deem it essential to have feedback sessions once or twice a year so that problematic issues are discussed or resolutions that work well are shared. These can be part of the regular meetings with the heads of Divisions, or a separate meeting with other role players in management positions in the Department. There may be engagements regarded as group supervision meetings where interested students are also allowed to attend so that, as Tinto $(1975,2002)$ 
claims, agreeable social interactions can improve student success. If, as Abdulla and Evans (2012) suggest, there is a positive correlation between student-confidence and -competency and their proactive engagement with their research experiences, their perceptions thereof will impact positively upon the supervision relationship. Cooperation between supervisor and student and clear delineation of roles is necessary to provide greater opportunities for master's students to succeed. The authors concur therefore with Mouton $(2007,1090)$ who calls attention to 'systemic issues' that require greater attention in order to alleviate the supervisory conditions and improve relationships and knowledge to allow for master's students to successfully complete their programmes.

The authors wish to acknowledge the contributions of Dr. H. Menkveld, the Faculty of Medicines and Health Sciences at Stellenbosch University, FIRLT, the Ethics Committee of the Faculty of Medicines and Health Sciences, Ms. R. Bloem, Dr. R. Albertyn and Prof. D. G. Nel to the larger study.

\section{REFERENCES}

Adeyemi, M. B. and A. A. Adeyinka. 2003. The principles and content of African Traditional Education. Educational Philosophy and Theory 35(4): 425-440.

Akoojee, S. and M. Nkomo. 2007. Access and quality in South African higher education: The twin challenges of transformation. South African Journal of Higher Education 21(3): 385-399.

Albertyn, R. M., C. A. Kapp and E. M. Bitzer. 2008. Profiling exiting postgraduate students' performance and experiences. South African Journal of Higher Education 22(4): 749-772.

Badat, S. 2005. South Africa: Distance higher education policies for access, social equity, quality, and social and economic responsiveness in a context of the diversity of provision. Distance Education 26(2): 183-204.

Badat, S. 2008. Producing, transforming the social composition of, and retaining a new generation of academics. The Rhodes University Programme of Accelerated Development. Rhodes University University Leaders Forum: Developing and Retaining the Next Generation of Academics: 24 November 2008, La Palm Royal Beach Hotel, Accra, Ghana.

Badat, S. 2009. Theorising institutional change: Post-1994 South African higher education. Studies in Higher Education 34: 455-467.

Bitzer, E. M. 2007. Editorial: Supervising higher degrees as a scholarly practice. South African Journal of Higher Education 21(8): 1010-1019.

Bosch, A. and J. Taylor. 2011. A proposed framework of institutional research development phases. Journal of Higher Education Policy and Management 33(5): 443-457.

Bourdieu, P. 1986. The forms of capital. In Handbook of theory and research for the sociology of education, ed. J. Richardson, 241-258. New York: Greenwood.

Council on Higher Education. 2009. Higher Education Monitor no.7: Postgraduate Studies in South Africa A statistical Profile. Higher Education Monitor (The Council on Higher Education) 7, March.

Council on Higher Education. 2014. VitalStats Public Higher Education 2012.

Gebbie, K., B. D. Goldstein, D. I. Gregorio, W. Tsou, P. Buffler, D. Petersen, C. Mahan and G. B. Silver. 2007. The National Board of Public Health Examiners: Credentialing Public Health Graduates. 
Public Health Reports (1974) 122(4) (July to August): 435-440: Association of Schools of Public Health. http://www.jstor.org/stable/20057155 (accessed 11 August 2015).

Koen, Charlton. 2007. Postgraduate student retention and success: A South African case study. Cape Town: HSRC.

Madikizela-Madiya, N., B. B. Goba and T. Nkambule. 2013. Developing a researcher identity: A reflective narration of postgraduate students' supervision experiences in a research project. South African Journal of Higher Education 27(4): 941-952.

Maritz, J. and P. Prinsloo. 2015. A Bourdieusian perspective on becoming and being a postgraduate supervisor: The role of capital. Higher Education Research and Development 34(5): 972-985. DOI: 10.1080/07294360.2015.1011085. http://dx.doi.org/10.1080/07294360.2015.1011085

Mouton, J. 2007. Postgraduate studies in South Africa: Myths, misconceptions and challenges. South Africa Journal of Higher Education 21(8): 1078-1090.

National Planning Commission. 2011. National Development Plan. Pretoria: South African Government,.

Nsibande, R. 2007. Using 'currere’to re-conceptualise and understand best practices for effective research supervision. South African Journal of Higher Education 21(8): 1117-1125.

Olivier, M. A. J. 2007. Postgraduate supervision: For better or for worse? South African Journal of Higher Education 21(8): 1126-1141.

Scott, I. R., N. Yeld and J. Hendry. 2007. A case for improving teaching and learning in South African higher education. Higher Education Monitor 6: iii-v. http://www.che.ac.za/documents/ d000155/HE_Monitor_6_ITLS_Oct2007

Swanepoel C. H. 2010. Master's degree studies: Expectations versus reality. South African Journal of Higher Education 24(1): 132-144

Tinto, V. 1975. Dropouts from higher education: A theoretical synthesis of recent research. Review of Educational Research 45: 89-125.

Tinto, V. 2002. Linking learning and leaving: Exploring the role of the college classroom in student departure. In Reworking the student departure puzzle, ed. J. Braxton. Nashville: Vanderbilt University Press,.

University of Stellenbosch. 2013. Teaching and Learning Policy. http://www.sun.ac.za/

Van Biljon, J. A. and E. de Kock. 2011. Multiplicity in supervision relationships: A factor in improving throughput succes. South African Journal of Higher Education 25(5): 987-1002.

Waghid, Y. 2011. On Cavellian scepticism and postgraduate student supervision. South African Journal of Higher Education 25(3): 393-396.

Wilkinson, A. C. 2011. Postgraduate supervision as an advanced teaching and learning practice: Exploring the scholarship link. South African Journal of Higher Education 25(5): 902-920.

Winberg, C., V. Barnes, K. Ncube and S. Tshinu. 2011. Postgraduate students' experiences in interdisciplinary research studies. South African Journal of Higher Education 25(5): 1003-1019. 